\title{
Analysis of E-Commerce Adoption by SMEs Using the Technology - Organization - Environment (TOE) Model: A Case Study in Karawang, Indonesia
}

\author{
Lila Setiyani $^{1}$, Yeny Rostiani ${ }^{2}$ \\ ${ }^{1}$ Information Systems Study Program, STMIK Rosma \\ ${ }^{2}$ Accounting Computerized Study Program, STMIK Rosma \\ Karawang, Jawa Barat 41311, Indonesia \\ * Corresponding author: \\ Email: lila.setiyani@dosen.rosma.ac.id
}

\begin{abstract}
.
E-commerce as a medium for online transactions by business actors can increase the productivity of SMEs. This study aims to analyze the adoption of ecommerce in SMEs in Karawang Regency, Indonesia. The technologyorganization-environment (TOE) framework was chosen as a variable for measuring e-commerce adoption. Data collection was carried out through a questionnaire survey which was distributed to SMEs in Karawang Regency, and obtained 301 respondents. The results of data collection by using Smart $P L S$ with the results of the technological aspects have no significant effect on the intention to adopt e-commerce, while the organizational and environmental aspects have a significant effect on the intention to adopt e-commerce. All technology indicators, namely compatability, perceived usefulness, complexity, security concern and relative advantage, are proven to have a significant effect on technology in the intention to adopt e-commerce. Organizational indicators, namely cost, organization readiness, organization culture, organization size and top management support, are proven to have a significant effect on organizations in their intention to adopt e-commerce. Meanwhile, environmental indicators, namely government support, competitive pressure, environmental uncertainty and vendor quality, have a significant effect on the environment in the intention to adopt e-commerce. The data that has been generated can be used by the MSMEs management agency in Karawang Regency to formulate strategies for increasing the productivity of SMEs.
\end{abstract}

Keywords: Adoption of E-Commerce, SMEs, TOE

\section{INTRODUCTION}

SMEs (Small and Medium Enterprises) has an extremely important contribution to economic growth and the growth of the country's development. Based on data from the Ministry of Cooperatives and Small and Medium Enterprises of the Republic of Indonesia from 2017 to 2018, there were 26,043 small business units and 2,075 medium-sized business units [1]. The rapid development of SMEs cannot be separated from the efforts that involve the adoption of technology. Several studies have revealed that business such as the use of e-commerce [2][3][4][5], digital marketing training [6][7], the use of digital marketing [8] can increase the productivity of SMEs.

The results of research by Purwantini \& Anisa (2018) report that social commerce has a positive impact in supporting customer service performance, sales, 
marketing and internal operations [9]. In line with this, Mumtahana, et.al (2017) revealed that e-commerce can boost the income of SMEs and MSMEs (Micro, Small and Medium Enterprises), by utilizing it as a marketing strategy [10]. This is also reinforced by research by Helmalia \& Afrinawati (2018) which states that e-commerce is proven to have a significant effect on the income of MSMEs [11].

E-Commerce is a commercial activity that takes place on the internet by utilizing digital technology [12]. Electronic commerce (e-commerce) occurs indirectly between customers and merchants via online platforms. The important difference between traditional trade and e-commerce is the transaction processing between the seller and the buyer that is separate and facilitated by software that allows virtual viewing of goods, a shopping cart and a secure payment system and delivery channel. Ecommerce customers can be accessed via the internet. By eliminating the physical interaction component of traditional trade, e-commerce also enables producers to act as merchants who are directly connected to customers without retailers acting as intermediaries [13].

Karawang as a district in West Java province has a lot of potential to increase the regional economy through increasing the productivity of SMEs and MSMEs. In March 2016 digital media Merdeka.Com reported that according to the Head of the Karawang Cooperative and MSMEs Office, Asep Junaedi there were at least 38,904 MSMEs [14]. Meanwhile, in November 2020, digital media Tempo.co reported that there were 87,574 MSMEs in Karawang registered to receive capital assistance [15]. Seeing the rapid growth of MSMEs in the last five years, of course, there are many factors that influence it. Based on the results of research that have been previously disclosed, that e-commerce has a role in increasing the productivity of SMEs and MSMEs. This attracts researchers to conduct related studies, the adoption of e-commerce by business actors, especially SMEs in Karawang Regency. The results of this study can provide benefits to the Karawang Regency Government, in order to identify factors that support or influence the adoption of e-commerce by SMEs in Karawang Regency in order to increase the productivity of their businesses.

To measure the adoption of a technology, there are many theories that can be used, including the Technology Acceptance Model (TAM) [16][17], Theory of Planned Behaviour (TPB) [18][19], unified theory of acceptance and use of technology (UTAUT) [20], TOE framework [21].

In this study, researchers used the TOE framework because this framework identifies three aspects, namely the technological, organizational and environmental contexts that affect an organization or in this case business actors (SMEs) in implementing, adopting and using technological innovations. By using the TOE framework, it can be seen which aspects can be improved in order to boost the productivity of business actors (SMEs). Based on the description of the background and the theory chosen by the researcher, in this study, the researcher determined the title of this study was "Analysis of E-Commerce Adoption by SMEs Using the 
Technology - Organization - Environment (TOE) Model: A Case Study in Karawang, Indonesia". Information on aspects or factors that drive the productivity of business actors (SMEs) in Karawang Regency in adopting e-commerce can be an evaluation material and become material in developing strategies for increasing the productivity of SMEs by the Karawang Regency Government, especially the Karawang Cooperative and MSMEs Office.

a. Technology Factor

The technology context includes all technologies that are relevant to the company, both existing and existing technologies available in the market, which are not currently used by the company. According to Collins et.al (1988) in [22] explained that the company's existing technology is important in the adoption process because it sets broad limits on the scope and speed of technological change that companies can undertake. In addition, innovations that exist but have not been used in companies also influence innovation, both by sharing what is possible and by showing companies the ways in which technology enables them to evolve and adapt.

According to Tushman and Nadler (1986) in [22] explained that in the innovation group that exists outside the company, there are three types of innovation that change, namely additional, synthetic or intermittent. Innovations that result in incremental changes introduce new features or new versions of existing technologies. This additional innovation represents the least amount of risk and change that it adopts, for example an increase in the ERP variant of a company. Synthesis innovation is the midpoint of moderate change, where ideas or technology are combined in new ways, for example e-learning used by universities.

1) Compatability

Rogers Everett (1995) describes compatibility as the extent to which an innovation is considered consistent with existing values, past experiences and adoption needs [23]. Therefore, when SMEs consider that e-commerce is compatible with their business, they will tend to continue to use it, which in turn benefits their business performance.

2) Perceived usefulness

Perceived usefulness according to Davis (1998) refers to the extent to which an individual believes that using certain technologies will improve their performance [24].

3) Relative Adavantage

Relative advantage can be defined as the extent to which a business views the benefits of using e-commerce [23]. Relative advantege is the level of ecommerce consistency that can provide business benefits, this level of ecommerce consistency is related to innovation, so the extent to which 
innovation can offer many business benefits through increased efficiency [25].

4) Complexity

Rogers Everett (1995) defines complexity as the difficulty of innovation to be understood and applied to achieve business goals, which requires more effort to find ways to use innovation [23]. According to Premkumar and Roberts (1999), it is assumed that, in this case, complexity has a negative impact on the adoption rate. Therefore, SMEs are likely to refuse to continue using innovation in their business when they find it too complex. In addition, the complexity in the system may affect the performance of the company because it may be too complex to measure the system from the start, and the process may continue to be difficult to understand, thus, it can be assumed that the more complex the system, the greater the negative impact on company performance.

5) Secuirity Concerns

Security issues involve a security attack on a business that destroys information [25]. Security concerns can be expressed as the level of business confidence in e-commerce services in the protection of company information secrets. According to Clear (2007) in [24] Security is defined as the extent to which the internet platform is assumed to be unsafe for online transactions. Besides that, Sahandi et.al in [24] also added that currently, security risks are increasing as computer networks become more complex. Security issues can be viruses, hacking, data interception which are the main concerns in doing business over the internet.

b. Organization Factor

According to [23] Organizational context refers to the characteristics of the company and its resources, size, scope, and structure.

1) Cost

Perceived costs are measured in financial investment and administrative costs. Previous studies by Alshamaila et. al (2013), Raut et.al (2019) and Verma et.al (2017) in [26] explained that the perceived cost is very important in the adoption of a technology.

2) Organization Readiness

Business readiness refers to the availability of a company in implementing a technology. The availability includes infrastructure, finance, information technology and human resources [25]. So that organizational readiness is a company's technical readiness to be able to innovate.

3) Top Management Support

Top management refers to the mindset of top management in supporting related technologies and the breadth of funding for implementation [25]. This support is one of the important aspects in supporting and completing the tools 
needed for new or innovative technologies. Top management plays a role since the implementation of creativity which requires the integration of resources and re-engineering of the business structure. Support from top management is a prerequisite where top management encourages acceptance of company creativity.

4) Organization size

According to [27] Organization size reflects that the larger the organization tends to adopt more information technology innovations in terms of flexibility and risk, and vice versa..

5) Organization Culture

Organizational culture according to Liu et.al (2010) in [28] refers to the combination of several general characteristics in an organization in employees such as norms, assumptions, beliefs and values. Khazanchi et.al (2007), Liu et.al (2010) and Mohtaramzadeh et.al (2018) in [28] stated that researchers pay more attention to organizational culture because it plays an important role in the acceptance of a new technology in the organization. Qashoua and Saleh (2018) in [28] reinforce with the statement that organizational culture is a key factor for technology adoption in an organization.

c. Environment Factor

According to [23] The environmental context relates to the industry or type of business and takes into account competitors, markets, government and external support.

1) Government Support

Government support can be defined as initiatives and opportunities from the government to encourage adoption [25].

2) Competitive Pressure

Competitive pressure refers to the extent to which an organization reacts to competitor pressure, thus encouraging the company to use new technology [25]. It can be concluded that competitive pressure is an organization's reaction to competitive pressure and compliance with industry requirements.

3) Environment Uncertainly

An environment full of uncertainty can undermine the use of new technology. Environmental insecurity occurs when there are complex and rapid changes. Organizations in high uncertainty may not adopt new technologies without clear infrastructure support and operating standards. This uncertainty has an impact on the reluctance to adopt information technology [29].

4) Vendor Quality

Vendor quality from e-commerce is related to several factors including reputation, reliability, support and shared value creation by suppliers and companies [30]. This suggests that the reputation of the software supplier 
affects adoption. In addition, it also deals with aspects of training in use and technical support for implementation and use.

d. Framework Development

The procedure for developing the model begins with conducting a content analysis of the literature to look for articles related to e-commerce adoption, then the selected articles are analyzed and then classified the factors that drive e-commerce adoption. The factors are classified into 3 categories, namely technology, organization, environment. The results of this categorization are then built an ecommerce adoption model. The following is a proposed conceptual framework for e-commerce adoption.

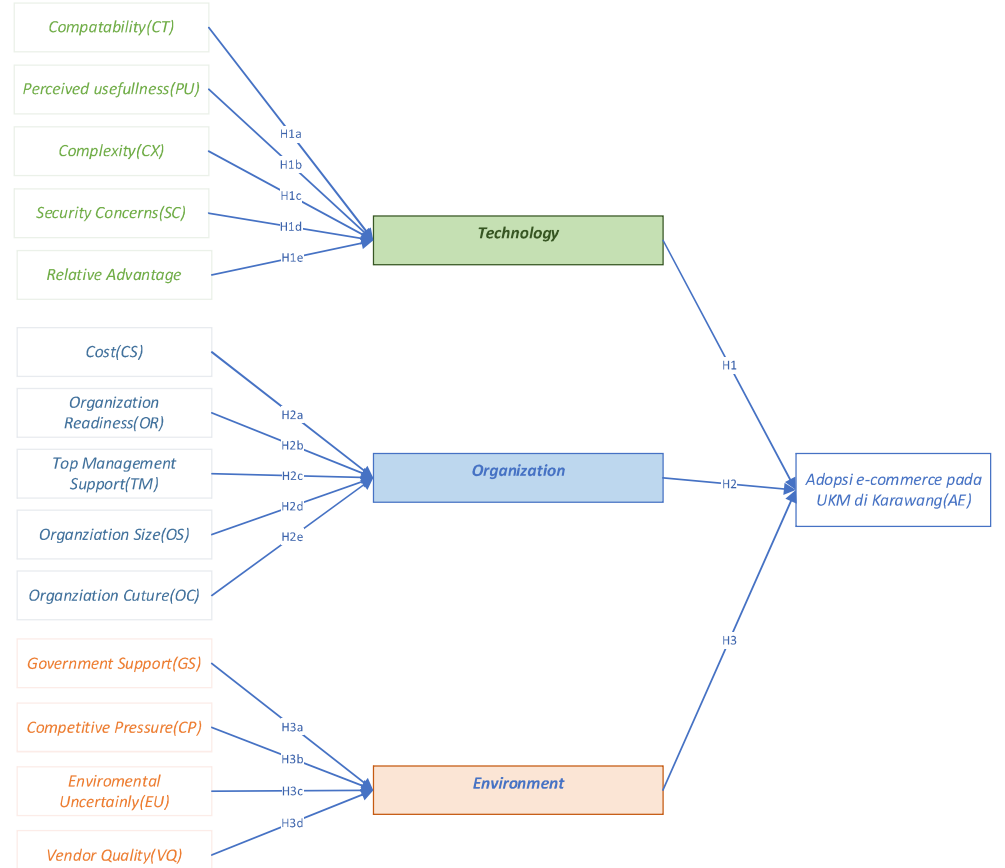

Fig 1. TOE Model

Based on the framework above, the following hypothesis can be formulated:

H1 Technology is thought to have a positive effect on e-commerce adoption by SMEs in Karawang Regency.

H1a. Compatibility is thought to have a positive effect on technology in terms of adopting e-commerce

H1b. Perceived Usefulness is thought to have a positive effect on technology in the intention to adopt e-commerce

H1c. Complexity is thought to have a positive effect on technology in the intention to adopt e-commerce

H1d. Security Concern is thought to have a positive effect on technology in its intention to adopt e-commerce 
H1e. Realative Advantage is thought to have a positive effect on technology in the intention to adopt e-commerce

$\mathrm{H} 2$ Organization is thought to have a positive effect on e-commerce adoption by SMEs in Karawang Regency.

H2a. Cost is thought to have a positive effect on organizations in their intention to adopt e-commerce

$\mathrm{H} 2 \mathrm{~b}$. Organization Readiness is thought to have a positive effect on organizations in their intention to adopt e-commerce

H2c. Organization Size is thought to have a positive effect on organizations in their intention to adopt e-commerce

H2d. Organization Culture is thought to have a positive effect on organizations in their intention to adopt e-commerce

H2e. Top Management Support is thought to have a positive effect on organizations in their intention to adopt e-commerce

The H3 Environment is thought to have a positive effect on e-commerce adoption by SMEs in Karawang Regency.

H3a. Government support is thought to have a positive effect on the environment in the intention to adopt e-commerce

H3b. Competitive Pressure is thought to have a positive effect on the environment in the intention to adopt e-commerce

H3c. Environmental Uncertainly is thought to have a positive effect on the environment in the intention to adopt e-commerce

$\mathrm{H} 3 \mathrm{~d}$. Vendor Quality is thought to have a positive effect on the environment in the intention to adopt e-commerce

\section{METHODS}

In this study, the data collection method used a quantitative approach represented by a questionnaire survey to collect primary data. The population of this research is SMEs in Karawang Regency. Samples were taken using purposive nonprobability sampling method. The questionnaire was built with the following constructs:

Table 1. TOE Construct

\begin{tabular}{|c|c|c|c|}
\hline Variable & Indicator & $\begin{array}{ll}\text { Source } \\
\end{array}$ & \\
\hline \multirow[t]{5}{*}{ Technology } & Compatability & {$[31],[32],[29],[33],[26],[25],[23],[28]$} & \\
\hline & $\begin{array}{l}\text { Perceived } \\
\text { usefullness }\end{array}$ & {$[24]$} & \\
\hline & $\begin{array}{l}\text { Relative } \\
\text { Adavantage }\end{array}$ & [31], [32], [29], [33], [34], [25], [23], [28] & \\
\hline & Complexity & {$[31],[29],[33],[25],[23],[28]$} & 1119 \\
\hline & $\begin{array}{l}\text { Secuirity } \\
\text { Concerns }\end{array}$ & [24], [33], [25], [28] & \\
\hline
\end{tabular}




\begin{tabular}{|c|c|c|}
\hline Variable & Indicator & Source \\
\hline \multirow{5}{*}{ Organization } & Cost & {$[29],[33],[26]$} \\
\hline & $\begin{array}{l}\text { Organizational } \\
\text { Readiness }\end{array}$ & [31], [24], [25], [35], [28] \\
\hline & $\begin{array}{l}\text { Top } \\
\text { Management } \\
\text { Support }\end{array}$ & [31], [32], [24], [29], [33], [36], [34], [26], [25], [28] \\
\hline & $\begin{array}{l}\text { Organization } \\
\text { size }\end{array}$ & {$[33],[36],[37]$} \\
\hline & $\begin{array}{l}\text { Organization } \\
\text { Culture }\end{array}$ & {$[38],[26],[28]$} \\
\hline \multirow[t]{4}{*}{ Environment } & $\begin{array}{l}\text { Government } \\
\text { Support }\end{array}$ & {$[32],[29],[36],[38],[25],[35],[37],[28]$} \\
\hline & $\begin{array}{l}\text { Competitive } \\
\text { Pressure }\end{array}$ & [31], [32], [24], [29], [36], [34], [26], [25], [23], [28] \\
\hline & $\begin{array}{l}\text { Environment } \\
\text { Uncertainly }\end{array}$ & [29] \\
\hline & Vendor Quality & {$[24],[23]$} \\
\hline
\end{tabular}

Table 2. Research Instruments

\begin{tabular}{|c|c|c|c|}
\hline Indikator & Deskripsi & Kode & Pernyataan \\
\hline \multicolumn{4}{|c|}{ Technology } \\
\hline \multirow[t]{2}{*}{$\begin{array}{l}\text { Compatability } \\
\text { (CT) }\end{array}$} & \multirow{2}{*}{$\begin{array}{l}\text { The extent to which an } \\
\text { e-commerce innovation } \\
\text { is considered consistent } \\
\text { with values so as to } \\
\text { benefit SMEs }\end{array}$} & CT1 & $\begin{array}{l}\text { The use of e-commerce consistently } \\
\text { provides beneficial value for the SMEs I } \\
\text { own or the SMEs I work for }\end{array}$ \\
\hline & & CT2 & $\begin{array}{l}\text { The innovations contained in e- } \\
\text { commerce have significantly increased } \\
\text { the profits of my SMEs or my SMEs to } \\
\text { work }\end{array}$ \\
\hline \multirow[t]{3}{*}{$\begin{array}{l}\text { Perceived } \\
\text { usefullness } \\
(P U)\end{array}$} & \multirow{3}{*}{$\begin{array}{l}\text { To what extent do } \\
\text { SMEs believe that using } \\
\text { e-commerce will } \\
\text { improve their business }\end{array}$} & PU1 & $\begin{array}{l}\text { I believe that e-commerce will increase } \\
\text { the productivity of my SMEs or the } \\
\text { SMEs I work for }\end{array}$ \\
\hline & & PU2 & $\begin{array}{l}\text { I find e-commerce useful for my SMEs } \\
\text { or the SMEs I work for }\end{array}$ \\
\hline & & PU3 & $\begin{array}{l}\text { By using e-commerce services to } \\
\text { customers becomes faster }\end{array}$ \\
\hline \multirow[t]{3}{*}{$\begin{array}{l}\text { Relative } \\
\text { Advantage } \\
\text { (RA) }\end{array}$} & \multirow{3}{*}{$\begin{array}{lr}\text { The extent } & \text { to } \\
\text { commerch e- } \\
\text { business } & \text { offers } \\
\text { through } & \text { benefits } \\
\text { efficiency } & \text { increased }\end{array}$} & RA1 & $\begin{array}{l}\text { The use of e-commerce increases the } \\
\text { efficiency of time in service to customers } \\
\text { at my SMEs or SMEs where I work }\end{array}$ \\
\hline & & RA2 & $\begin{array}{l}\text { The use of e-commerce increases the } \\
\text { efficiency of operational costs at the } \\
\text { SMEs owned by me or the SMEs where } \\
\text { I work }\end{array}$ \\
\hline & & RA3 & $\begin{array}{l}\text { The use of e-commerce increases the } \\
\text { efficiency of human resources at the } \\
\text { SMEs I own or the SMEs I work for }\end{array}$ \\
\hline $\begin{array}{l}\text { Complexity } \\
(C X)\end{array}$ & $\begin{array}{l}\text { The difficulty of e- } \\
\text { commerce to understand } \\
\text { and apply to achieve } \\
\text { business goals }\end{array}$ & CX1 & $\begin{array}{l}\text { The process of understanding e- } \\
\text { commerce used by my } \\
\text { SMEs or the SMEs I work } \\
\text { for is very easy }\end{array}$ \\
\hline
\end{tabular}




\begin{tabular}{|c|c|c|c|}
\hline Indikator & Deskripsi & Kode & Pernyataan \\
\hline & & $\mathrm{CX} 2$ & $\begin{array}{l}\text { It's easy to learn about the e-commerce } \\
\text { used by my SMEs or the SMEs I work } \\
\text { for }\end{array}$ \\
\hline \multirow[t]{2}{*}{$\begin{array}{l}\text { Security } \\
\text { concerns (SC) }\end{array}$} & \multirow{2}{*}{$\begin{array}{lr}\text { The level of business } \\
\text { confidence } & \text { in e- } \\
\text { commerce } & \text { services in } \\
\text { protecting } & \text { SMEs } \\
\text { information } & \text { and } \\
\text { transactions } & \end{array}$} & $\mathrm{SC} 1$ & $\begin{array}{l}\text { The level of information security from e- } \\
\text { commerce that is used by my SMEs or } \\
\text { the SMEs I work for is a consideration in } \\
\text { implementing e-commerce }\end{array}$ \\
\hline & & $\mathrm{SC} 2$ & $\begin{array}{l}\text { The level of transaction security in e- } \\
\text { commerce used by my SMEs or the } \\
\text { SMEs I work for is my consideration in } \\
\text { implementing e-commerce }\end{array}$ \\
\hline \multicolumn{4}{|c|}{ Organization } \\
\hline \multirow[t]{2}{*}{ Cost (CS) } & \multirow[t]{2}{*}{$\begin{array}{l}\text { Perceived costs of e- } \\
\text { commerce adoption by } \\
\text { SMEs }\end{array}$} & CS1 & $\begin{array}{l}\text { The amount of costs incurred in } \\
\text { implementing e-commerce at my SMEs } \\
\text { or the SMEs where I work is a } \\
\text { consideration in implementing e- } \\
\text { commerce }\end{array}$ \\
\hline & & $\mathrm{CS} 2$ & $\begin{array}{l}\text { The operational costs incurred in } \\
\text { implementing e-commerce at my SMEs } \\
\text { or the SMEs where I work are taken into } \\
\text { consideration in implementing e- } \\
\text { commerce }\end{array}$ \\
\hline \multirow[t]{4}{*}{$\begin{array}{l}\text { Organization } \\
\text { readiness } \\
(O R)\end{array}$} & \multirow{4}{*}{$\begin{array}{l}\text { Willingness of SMEs in } \\
\text { implementing } \\
\text { commerce } \\
\text { includes the readiness of } \\
\text { infrastructure, finance, } \\
\text { technology and human } \\
\text { resources }\end{array}$} & OR1 & $\begin{array}{l}\text { My SMEs or the SMEs I work for have } \\
\text { the financial resources to adopt e- } \\
\text { commerce }\end{array}$ \\
\hline & & OR2 & $\begin{array}{l}\text { My SMEs or the SMEs I work for has } \\
\text { the technological resources to adopt e- } \\
\text { commerce }\end{array}$ \\
\hline & & OR3 & $\begin{array}{l}\text { My SMEs or the SMEs I work for has } \\
\text { sufficient internet connectivity to adopt } \\
\text { e-commerce }\end{array}$ \\
\hline & & OR4 & $\begin{array}{l}\text { Human resources in my SMEs or SMEs } \\
\text { where I work have the competence to } \\
\text { use e-commerce }\end{array}$ \\
\hline \multirow[t]{3}{*}{$\begin{array}{l}\text { Top } \\
\text { management } \\
\text { support (TM) }\end{array}$} & \multirow{3}{*}{$\begin{array}{l}\text { Top management's } \\
\text { mindset in supporting } \\
\text { the implementation of e- } \\
\text { commerce in terms of } \\
\text { funding and policies }\end{array}$} & TM1 & $\begin{array}{l}\text { As an owner of an SMEs or an owner of } \\
\text { an SMEs where I work, I am willing to } \\
\text { be involved in the adoption of e- } \\
\text { commerce }\end{array}$ \\
\hline & & TM2 & $\begin{array}{l}\text { As an owner of an SMEs or an owner of } \\
\text { an SMEs where I work, I consider the } \\
\text { adoption of e-commerce as an important } \\
\text { strategy }\end{array}$ \\
\hline & & TM3 & $\begin{array}{l}\text { As an owner of an SMEs or an owner of } \\
\text { an SMEs where I work, I consider the } \\
\text { adoption of e-commerce as a strategy to } \\
\text { gain a competitive advantage }\end{array}$ \\
\hline $\begin{array}{l}\text { Organization } \\
\text { size (OS) }\end{array}$ & $\begin{array}{l}\text { Organizational size that } \\
\text { reflects the flexibility } \\
\text { and risk in adopting e- } \\
\text { commerce }\end{array}$ & OS1 & $\begin{array}{l}\text { The size of my SMEs organization or the } \\
\text { SMEs I work for affects } \\
\text { the speed at which e- } 1121 \\
\text { commerce is implemented }\end{array}$ \\
\hline
\end{tabular}




\begin{tabular}{|c|c|c|c|}
\hline Indikator & Deskripsi & Kode & Pernyataan \\
\hline $\begin{array}{l}\text { Organization } \\
\text { Culture (OC) }\end{array}$ & $\begin{array}{l}\text { The combination of } \\
\text { general characteristics } \\
\text { of SMEs in this regard } \\
\text { are norms, assumptions } \\
\text { and values }\end{array}$ & OC1 & $\begin{array}{l}\text { The organizational culture of my SMEs } \\
\text { or the SMEs where I work affects the } \\
\text { success of implementing e-commerce }\end{array}$ \\
\hline \multicolumn{4}{|c|}{ Environment } \\
\hline $\begin{array}{l}\text { Government } \\
\text { Support }(G S)\end{array}$ & $\begin{array}{l}\text { Government initiatives } \\
\text { and opportunities in } \\
\text { encouraging } \\
\text { commerce adoption }\end{array}$ & GS1 & $\begin{array}{l}\text { The government provides e-commerce } \\
\text { training to the SMEs I own or the SMEs } \\
\text { I work for, in order to encourage e- } \\
\text { commerce adoption }\end{array}$ \\
\hline \multirow[t]{2}{*}{$\begin{array}{l}\text { Competitive } \\
\text { pressure }(C P)\end{array}$} & \multirow[t]{2}{*}{$\begin{array}{l}\text { The extent to which } \\
\text { SMEs react to } \\
\text { competitor pressure }\end{array}$} & $\mathrm{CP} 1$ & $\begin{array}{l}\text { Competitors are encouraging my SMEs } \\
\text { or the SMEs I work to adopt e- } \\
\text { commerce }\end{array}$ \\
\hline & & $\mathrm{CP} 2$ & $\begin{array}{l}\text { My SMEs or the SMEs I work for will } \\
\text { suffer from competitors if they don't } \\
\text { adopt e-commerce }\end{array}$ \\
\hline $\begin{array}{l}\text { Environment } \\
\text { uncertainly } \\
(E U)\end{array}$ & $\begin{array}{l}\text { Environmental } \\
\text { uncertainty of SMEs in } \\
\text { adopting e-commerce }\end{array}$ & EU1 & $\begin{array}{l}\text { The uncertainty of environmental change } \\
\text { in my SMEs or the SMEs I work for is } \\
\text { driving e-commerce adoption }\end{array}$ \\
\hline \multirow[t]{3}{*}{$\begin{array}{l}\text { Vendor } \\
\text { quality }(V Q)\end{array}$} & \multirow{3}{*}{$\begin{array}{l}\text { Quality of an e- } \\
\text { commerce vendor in } \\
\text { terms of reputation, } \\
\text { reliability, support and } \\
\text { value creation }\end{array}$} & VQ1 & $\begin{array}{l}\text { The reputation of the e-commerce } \\
\text { provider is important in choosing the } \\
\text { right e-commerce for my SMEs or the } \\
\text { SMEs I work for }\end{array}$ \\
\hline & & VQ2 & $\begin{array}{l}\text { The competency of e-commerce } \\
\text { technology presented by the provider is } \\
\text { very important when choosing e- } \\
\text { commerce for my SMEs or the SMEs } \\
\text { where I work }\end{array}$ \\
\hline & & VQ3 & $\begin{array}{l}\text { E-commerce providers provide usage } \\
\text { guidelines to make it easier for my } \\
\text { SMEs or the SMEs I work for in the e- } \\
\text { commerce implementation process }\end{array}$ \\
\hline \multicolumn{4}{|c|}{ Adoption e-commerce } \\
\hline \multirow{2}{*}{$\begin{array}{l}\text { Adoption e- } \\
\text { commerce } \\
(A C)\end{array}$} & \multirow[t]{2}{*}{$\begin{array}{l}\text { The use of e-commerce } \\
\text { by SMEs }\end{array}$} & $\mathrm{AC} 1$ & $\begin{array}{l}\text { My SMEs or SMEs where I work use e- } \\
\text { commerce in managing their business }\end{array}$ \\
\hline & & $\mathrm{AC} 2$ & $\begin{array}{l}\text { My SMEs or SMEs where I work has } \\
\text { implemented e-commerce completely }\end{array}$ \\
\hline
\end{tabular}

Data collection was carried out by distributing questionnaires via google form and print media. Google form is spread through social media, groups, MSMEs forums, and Whatsapp. Meanwhile, printed questionnaires were distributed door-to-door visiting SMEs around the crowded areas in Karawang Regency. In the data collection process, it was found that many SMEs were reluctant to fill out questionnaires. This reluctance was eliminated because SMEs assessed that there was no value for them. From the data collection process, there were 301 respondents. 


\section{RESULT AND DISCUSSION}

The survey results were analyzed using Structural Equation Modeling (SEM) with Smart PLS 3.

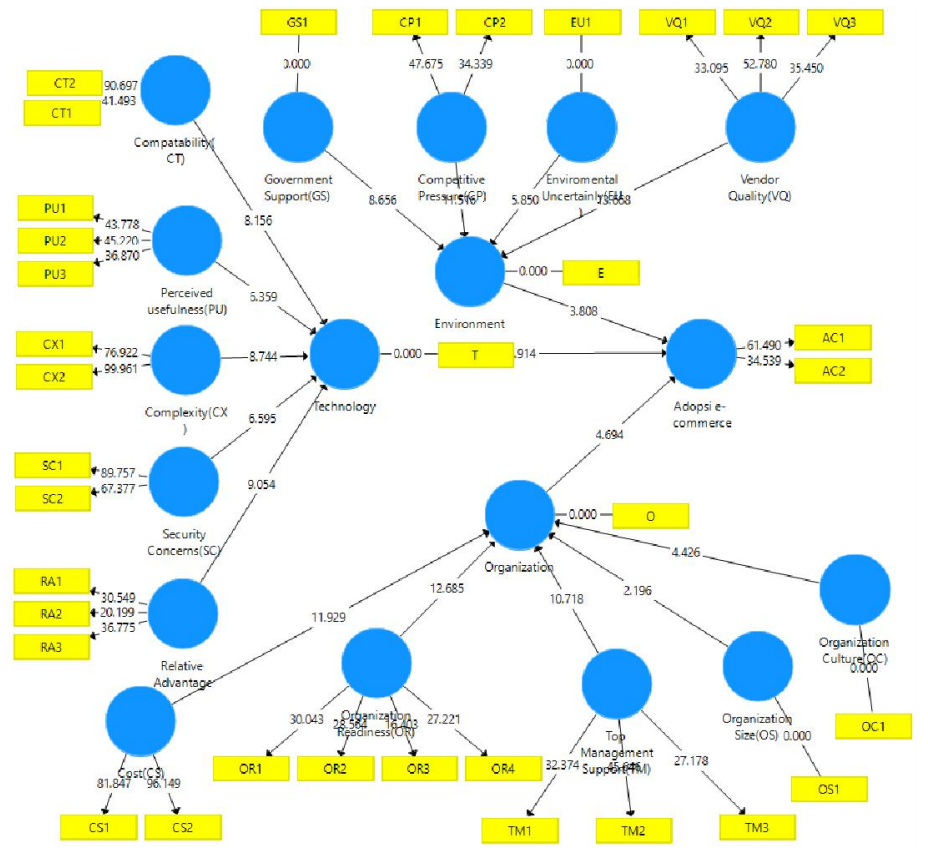

Fig 1. Structural Research Model

a. Demographic Data

Table 3. Demographic Analysis Results

\begin{tabular}{|ccccc|}
\hline Variable & Type & Frequency & Percent & $\begin{array}{c}\text { Percent } \\
\text { Valid }\end{array}$ \\
\hline $\begin{array}{c}\text { E-commerce } \\
\text { Users }\end{array}$ & $\begin{array}{c}\text { Already using E- } \\
\text { Commerce } \\
\text { Not using E- }\end{array}$ & 271 & $90 \%$ & $90 \%$ \\
& Commerce yet & 30 & $10 \%$ & $10 \%$ \\
\hline Vendor E- & Tokopedia & 43 & $14.3 \%$ & $14.3 \%$ \\
commerce & Shopee & 64 & $21.3 \%$ & $21.3 \%$ \\
& Bukalapak & 22 & $7.3 \%$ & $7.3 \%$ \\
& Lazada & 18 & $6 \%$ & $6 \%$ \\
& Blibli & 12 & $4 \%$ & $4 \%$ \\
& Social Commerce & 209 & $69.4 \%$ & $69.4 \%$ \\
& (Facebook, & & & \\
& Instagram, etc.) & 87 & $28.9 \%$ & $28.9 \%$ \\
& Gofood & 92 & $30.6 \%$ & $30.6 \%$ \\
& Grabfood & 109 & $36 \%$ & $36 \%$ \\
\hline Others & 194 & $64.5 \%$ & $64.5 \%$ \\
& $<5$ years & 71 & $23.6 \%$ & $23.6 \%$ \\
& 5-10 years & 36 & $12 \%$ & $12 \%$ \\
\hline Number of & $>10$ years & 233 & $77.4 \%$ & $77.4 \%$ \\
\hline
\end{tabular}

http://ijstm.inarah.co.id 


\begin{tabular}{|ccccc|}
\hline Employees & & & & \\
& $6-20$ & 46 & $15.3 \%$ & $15.3 \%$ \\
& $>20$ & 22 & $7.3 \%$ & $7.3 \%$ \\
\hline Type of & Culinary & 160 & $53.2 \%$ & $53.2 \%$ \\
Business & & & \\
& Fashion & 45 & $15 \%$ & $15 \%$ \\
& Agribusiness & 12 & $4 \%$ & $4 \%$ \\
& Services & 28 & $9.3 \%$ & $9.3 \%$ \\
& Others & 56 & $18.6 \%$ & $18.6 \%$ \\
\hline Respondent & Employees & 150 & $50.7 \%$ & $50.7 \%$ \\
Position & & & & \\
& Business Owners & 146 & $49.3 \%$ & $49.3 \%$ \\
\hline
\end{tabular}

Based on table 3, respondents consist of $49.3 \%$ business owners and $50.7 \%$ employees. In addition, the type of business that is mostly occupied by SMEs is culinary, which is $53.2 \%$, and the most widely used e-commerce vendor is social commerce at $69.4 \%$.

b. Convergent Validity of The Measurement

Table 4. Constructs, Items, Confirmatory Factor Analysis

\begin{tabular}{|c|c|c|c|c|c|}
\hline & $\begin{array}{c}\text { Ite } \\
\text { m }\end{array}$ & $\begin{array}{l}\text { Loadin } \\
\mathrm{g}\end{array}$ & $\begin{array}{c}\text { Cronbach's } \\
\text { Alpha }\end{array}$ & $\begin{array}{l}\text { Composite } \\
\text { Reliability }\end{array}$ & $\begin{array}{c}\text { Average } \\
\text { Variance } \\
\text { Extracted } \\
\text { (AVE) }\end{array}$ \\
\hline \multirow[t]{2}{*}{ Compatability } & CT1 & 0.886 & 0.783 & 0.925 & 0.821 \\
\hline & $\mathrm{CT} 2$ & 0.925 & & & \\
\hline \multirow{3}{*}{$\begin{array}{l}\text { Perceived } \\
\text { Usefulness }\end{array}$} & PU1 & 0.859 & 0.814 & 0.890 & 0.729 \\
\hline & PU2 & 0.872 & & & \\
\hline & PU3 & 0.830 & & & \\
\hline \multirow[t]{2}{*}{ Complexity } & CX1 & 0.923 & 0.839 & 0.925 & 0.861 \\
\hline & $\mathrm{CX} 2$ & 0.933 & & & \\
\hline \multirow[t]{2}{*}{ Security Concern } & $\mathrm{SC} 1$ & 0.934 & 0.838 & 0.925 & 0.860 \\
\hline & $\mathrm{SC} 2$ & 0.920 & & & \\
\hline \multirow{3}{*}{$\begin{array}{l}\text { Relative } \\
\text { Advantage }\end{array}$} & RA1 & 0.809 & 0.746 & 0.855 & 0.662 \\
\hline & RA2 & 0.799 & & & \\
\hline & RA3 & 0.833 & & & \\
\hline Technology & $\mathrm{T}$ & 1.000 & 1.000 & 1.000 & 1.000 \\
\hline \multirow[t]{2}{*}{ Cost } & $\mathrm{CS} 1$ & 0.941 & 0.868 & 0.938 & 0.883 \\
\hline & $\mathrm{CS} 2$ & 0.938 & & & \\
\hline \multirow{4}{*}{$\begin{array}{l}\text { Organization } \\
\text { Readiness }\end{array}$} & OR1 & 0.818 & 0.794 & 0.866 & 0.618 \\
\hline & OR2 & 0.815 & & & \\
\hline & OR3 & 0.745 & & & \\
\hline & OR4 & 0.765 & & & \\
\hline Organization Size & OS1 & 1.000 & 1.000 & 1.000 & 1.000 \\
\hline $\begin{array}{l}\text { Organization } \\
\text { Culture }\end{array}$ & $\mathrm{OC} 1$ & 1.000 & 1.000 & 1.000 & 1.000 \\
\hline \multirow{3}{*}{$\begin{array}{l}\text { Top Management } \\
\text { Support }\end{array}$} & TM & 0.819 & 0.766 & 0.866 & 0.682 \\
\hline & $\begin{array}{l}\text { TM } \\
2\end{array}$ & 0.866 & & & \\
\hline & $\begin{array}{l}\mathrm{TM} \\
3\end{array}$ & 0.791 & & & \\
\hline Organization & $\mathrm{O}$ & 1.000 & 1.000 & 1.000 & 1.000 \\
\hline
\end{tabular}




\begin{tabular}{|c|c|c|c|c|c|}
\hline $\begin{array}{l}\text { Government } \\
\text { Support }\end{array}$ & GS1 & 1.000 & 1.000 & 1.000 & 1.000 \\
\hline \multirow{2}{*}{$\begin{array}{l}\text { Competitive } \\
\text { Pressure }\end{array}$} & $\mathrm{CP} 1$ & 0.864 & \multirow[t]{2}{*}{0.604} & \multirow[t]{2}{*}{0.834} & \multirow[t]{2}{*}{0.716} \\
\hline & $\mathrm{CP} 2$ & 0.827 & & & \\
\hline $\begin{array}{l}\text { Environmental } \\
\text { Uncertainly }\end{array}$ & EU1 & 1.000 & 1.000 & 1.000 & 1.000 \\
\hline \multirow[t]{3}{*}{ Vendor Quality } & VQ1 & 0.823 & \multirow[t]{3}{*}{0.807} & \multirow[t]{3}{*}{0.886} & \multirow[t]{3}{*}{0.722} \\
\hline & VQ2 & 0.880 & & & \\
\hline & VQ3 & 0.844 & & & \\
\hline Environmental & $\mathrm{E}$ & 1.000 & 1.000 & 1.000 & 1.000 \\
\hline \multirow{2}{*}{$\begin{array}{l}\text { E-commerce } \\
\text { Adoption }\end{array}$} & $\mathrm{AC} 1$ & 0.919 & \multirow[t]{2}{*}{0.762} & \multirow[t]{2}{*}{0.893} & \multirow[t]{2}{*}{0.806} \\
\hline & $\mathrm{AC} 2$ & 0.876 & & & \\
\hline
\end{tabular}

Based on the results of processing using Smart PLS that the resulting loading factor value for all items is more than 0.6 , this shows that the outer model between constructs and variables has met the convergent validity.

c. Discriminant of The Measurement

Disciplinary valdity is done to ensure that each concept of each latent model is different from other variables. Discriminant validity can be seen from the cross loading value. Cross loading on the model, shows that the loading value of each indicator item on the construct. In addition, to evaluate discriminant validity, it can be seen by using AVE (Average Variance Extracted) for each latent variable. The model has good discriminant validity if the square root of AVE for each construct is greater than the correlation between the two constructs in the model. The value of cross loading and AVE in this study after being analyzed has met the criteria for discriminant validity.

d. Composite reliability and Cronbach Alpha Measurement

Composite reliability measures the actual reliability value of a variable while Cronbach Alpha measures the lowest value of the reliability of a variable so that composite reliability $>0.6$ and Cronbach alpha value $>0.6$. Based on the analysis results show that the value of composite reliability and Cronbach alpha of all items $>0.6$, it can be stated that all constructs are reliable.

e. Model Structure Analysis

1) R-Square Value

Table 5. R-Square Value

\begin{tabular}{lcc} 
& R Square & R Square Adjusted \\
\hline E-commerce Adoption & 0.304 & 0.297 \\
Environment & 0.879 & 0.877 \\
Organization & 0.860 & 0.858 \\
Technology & 0.831 & 0.829
\end{tabular}

Table 5 above for the e-Commerce Adoption Variable gives a value of 0.304 which means that the technology, organization, environment variables are able to influence e-commerce adoption by $30 \%$ while the rest is influenced by other factors. For the Technology variable, it gives a value of 0.831 , which means the indicators of compatibility, perceived usefulness, relative 
advantage, complexity, security concerns are able to influence the technology variable by $83.1 \%$, while the rest is influenced by other factors. For the organization variable it gives a value of 0.860 which means indicators of cost, organizational readiness, top management support, organization size, organization culture are able to influence the organizational variables by $86 \%$, while the rest is influenced by other factors. The environment variable gives a value of 0.879 which means that the indicators of government support, competitive pressure, environmental uncertainty, and vendor support are able to influence the environmental variables by $87.9 \%$, while the rest is influenced by other factors.

2) Hypothesis Testing

Table 6. Original Samples, T Statistics

\begin{tabular}{|l|c|c|c|c|c|}
\hline & $\begin{array}{c}\text { Original } \\
\text { Sample } \\
(\mathbf{O})\end{array}$ & $\begin{array}{c}\text { Sampl } \\
\mathbf{e} \\
\text { Mean } \\
(\mathbf{M})\end{array}$ & $\begin{array}{c}\text { Standard } \\
\text { Deviatio } \\
\mathbf{n}\end{array}$ & $\begin{array}{c}\text { T Statistics } \\
(\mid \mathbf{O} / \text { STDEV }\end{array}$ & $\begin{array}{c}\text { P } \\
\text { Value } \\
\text { s }\end{array}$ \\
\hline $\begin{array}{l}\text { Compatability (CT) } \\
\rightarrow \text { Technology }\end{array}$ & 0,279 & 0,279 & 0,034 & 8,156 & $\mathbf{0 , 0 0 0}$ \\
\hline $\begin{array}{l}\text { Competitive Pressure } \\
\text { (CP) } \rightarrow \text { Environment }\end{array}$ & 0,356 & 0,356 & 0,031 & 11,516 & $\mathbf{0 , 0 0 0}$ \\
\hline $\begin{array}{l}\text { Complexity (CX) } \rightarrow \\
\text { Technology }\end{array}$ & 0,302 & 0,302 & 0,035 & 8,744 & $\mathbf{0 , 0 0 0}$ \\
\hline $\begin{array}{l}\text { Cost (CS) } \rightarrow \\
\text { Organization }\end{array}$ & 0,289 & 0,288 & 0,024 & 11,929 & $\mathbf{0 , 0 0 0}$ \\
\hline $\begin{array}{l}\text { Enviromental } \\
\text { Uncertainly (EU) } \rightarrow \\
\text { Environment }\end{array}$ & 0,180 & 0,182 & 0,031 & 5,850 & $\mathbf{0 , 0 0 0}$ \\
\hline $\begin{array}{l}\text { Environment } \rightarrow \text { E- } \\
\text { commerce Adoption }\end{array}$ & 0,288 & 0,289 & 0,076 & 3,808 & $\mathbf{0 , 0 0 0}$ \\
\hline $\begin{array}{l}\text { Government Support } \\
\text { (GS) } \rightarrow \text { Environment }\end{array}$ & 0,236 & 0,237 & 0,027 & 8,656 & $\mathbf{0 , 0 0 0}$ \\
\hline $\begin{array}{l}\text { Organization } \rightarrow \text { E- } \\
\text { commerce Adoption }\end{array}$ & 0,366 & 0,363 & 0,078 & 4,694 & $\mathbf{0 , 0 0 0}$ \\
\hline $\begin{array}{l}\text { Organization Culture } \\
\text { (OC) } \rightarrow \\
\text { Organization }\end{array}$ & 0,136 & 0,134 & 0,031 & 4,426 & $\mathbf{0 , 0 0 0}$ \\
\hline $\begin{array}{l}\text { Organization } \\
\text { Readiness (OR) } \rightarrow \\
\text { Organization }\end{array}$ & 0,407 & 0,409 & 0,032 & 12,685 & $\mathbf{0 , 0 0 0}$ \\
\hline $\begin{array}{l}\text { Organization Size } \\
\text { (OS) } \rightarrow \text { Organization }\end{array}$ & 0,066 & 0,066 & 0,030 & 2,196 & $\mathbf{0 , 0 2 9}$ \\
\hline $\begin{array}{l}\text { Perceived usefulness } \\
\text { (PU) } \rightarrow \text { Technology }\end{array}$ & 0,239 & 0,237 & 0,038 & 6,359 & $\mathbf{0 , 0 0 0}$ \\
\hline $\begin{array}{l}\text { Relative Advantage } \\
\rightarrow \text { Technology }\end{array}$ & 0,332 & 0,334 & 0,037 & 9,054 & $\mathbf{0 , 0 0 0}$ \\
\hline $\begin{array}{l}\text { Security Concerns } \\
\text { (SC) } \rightarrow \text { Technology }\end{array}$ & 0,218 & 0,219 & 0,033 & 6,595 & $\mathbf{0 , 0 0 0}$ \\
\hline
\end{tabular}




\begin{tabular}{|l|c|c|c|c|c|}
\hline & $\begin{array}{c}\text { Original } \\
\text { Sample } \\
(\mathbf{O})\end{array}$ & $\begin{array}{c}\text { Sampl } \\
\mathbf{e} \\
\text { Mean } \\
(\mathbf{M})\end{array}$ & $\begin{array}{c}\text { Standard } \\
\text { Deviatio } \\
\mathbf{n} \\
(\mathbf{S T D E V})\end{array}$ & $\begin{array}{c}\text { T Statistics } \\
(|\mathbf{O} / \mathbf{S T D E V}|\end{array}$ & $\begin{array}{c}\mathbf{P} \\
\text { Value } \\
\mathbf{~}\end{array}$ \\
\hline $\begin{array}{l}\text { Technology } \rightarrow \text { E- } \\
\text { commerce Adoption }\end{array}$ & $-0,070$ & $-0,070$ & 0,077 & 0,914 & $\mathbf{0 , 3 6 1}$ \\
\hline $\begin{array}{l}\text { Top Management } \\
\text { Support (TM) } \rightarrow \\
\text { Organization }\end{array}$ & 0,369 & 0,369 & 0,034 & 10,718 & $\mathbf{0 , 0 0 0}$ \\
\hline $\begin{array}{l}\text { Vendor Quality (VQ) } \\
\rightarrow \text { Environment }\end{array}$ & 0,423 & 0,421 & 0,031 & 13,668 & $\mathbf{0 , 0 0 0}$ \\
\hline
\end{tabular}

\section{Discussion of Hypotheses 1}

The results of testing the technology variable did not have a significant effect on e-commerce adoption with a $\mathrm{P}$ value of $0.361 \geq 0.05$ and a T-Statistics value of $0.914<\mathrm{t}$-table 1.96 thus $\mathrm{H} 1$ in this study was rejected.

a) $\mathrm{H} 1 \mathrm{a}$

The results of testing the compatibility indicators have a positive and significant effect on technology variables with a $P$ value of $0.000 \leq 0.05$ and a T-Statistic value of $8.156>\mathrm{t}$ - table 1.96 , thus H1a in this study is accepted.

b) $\mathrm{H} 1 \mathrm{~b}$

The results of the perceived usefulness indicator test have a positive and significant effect on technology with a $\mathrm{P}$ value of $0.000 \leq 0.05$ and a $\mathrm{T}$ Statistic value of $6.359>\mathrm{t}$-table 1.96 thus $\mathrm{H} 1 \mathrm{~b}$ in this study is accepted.

c) $\mathrm{H} 1 \mathrm{c}$

The test results of complexity indicators have a positive and significant effect on technology with a $\mathrm{P}$ value of $0.000 \leq 0.05$ and a T-Statistic value of $8.744>\mathrm{t}$-table 1.96 , thus H1c in this study is accepted.

d) H1d

The test results of security concern indicators have a positive and significant effect on technology with a $\mathrm{P}$ value of $0.000 \leq 0.05$ and a TStatistic value of 6,595 > t-table 1.96, thus H1d in this study is accepted.

e) $\mathrm{H} 1 \mathrm{e}$

The results of testing the relative advantage indicator have a positive and significant effect on technology with a $\mathrm{P}$ value of $0.000 \leq 0.05$ and a TStatistic value of $9,054>\mathrm{t}$-table 1.96 , thus H1e in this study is accepted.

\section{Discussion of Hypotheses 2}

The results of testing for organizational variables have a positive and significant effect on e-commerce adoption with a $P$ value of $0.000 \geq 0.05$ and a T-Statistics value of $4.694>$ t-table 1.96, thus $\mathrm{H} 2$ in this study is accepted.

a) $\mathrm{H} 2 \mathrm{a}$ 
The results of the cost indicator test have a positive and significant effect on organizations with a $\mathrm{P}$ value of $0.000 \leq 0.05$ and a T-Statistic value of $11,929>$ t-table 1.96, thus H2a in this study is accepted.

b) $\mathrm{H} 2 \mathrm{~b}$

The results of testing for organizational readiness indicators have a positive and significant effect on organizations with a $P$ value of $0.000 \leq$ 0.05 and a T-Statistic value of $12.685>\mathrm{t}$-table 1.96 , thus $\mathrm{H} 2 \mathrm{~b}$ in this study is accepted.

c) $\mathrm{H} 2 \mathrm{c}$

The test results of organization size indicators have a positive and significant effect on organizations with a $\mathrm{P}$ value of $0.029 \leq 0.05$ and a T-Statistic value of $2.196>\mathrm{t}$-table 1.96 , thus $\mathrm{H} 2 \mathrm{c}$ in this study is accepted.

d) $\mathrm{H} 2 \mathrm{~d}$

The results of testing for organizational culture indicators have a positive and significant effect on organizations with a $\mathrm{P}$ value of $0.000 \leq$ 0.05 and a T-Statistic value of $4.426>$ t-table 1.96 , thus $\mathrm{H} 2 \mathrm{~d}$ in this study is accepted.

e) $\mathrm{H} 2 \mathrm{e}$

The test results of the Top Management Support indicator have a positive and significant effect on organizations with a $\mathrm{P}$ value of $0.000 \leq$ 0.05 and a T-Statistic value of $10.718>\mathrm{t}$-table 1.96 , thus $\mathrm{H} 2 \mathrm{e}$ in this study is accepted.

\section{Discussion of Hypotheses 3}

The results of testing for organizational variables have a positive and significant effect on e-commerce adoption with a $P$ value of $0.000 \geq 0.05$ and a T-Statistics value of $3.808>$ t-table 1.96 thus $\mathrm{H} 3$ in this study is accepted.

a) $\mathrm{H} 3 \mathrm{a}$

The test results of the Goverment Support indicator have a positive and significant effect on the Environment with a $\mathrm{P}$ value of $0.000 \leq 0.05$ and a T-Statistic value of $8.656>$ t-table 1.96, thus the H3a in this study is accepted.

b) $\mathrm{H} 3 \mathrm{~b}$

The results of the Competitive Pressure indicator test have a positive and significant effect on the Environment with a $P$ value of $0.000 \leq 0.05$ and a T-Statistic value of $11.516>$ t-table 1.96 , thus $\mathrm{H} 3 \mathrm{~b}$ in this study is accepted.

c) $\mathrm{H} 3 \mathrm{c}$

The test results of the Environmental Uncertainly indicator have a positive and significant effect on the Environment with a $\mathrm{P}$ value of 
$0.000 \leq 0.05$ and a T-Statistic value of $5.850>$ t-table 1.96 , thus the $\mathrm{H} 3 \mathrm{c}$ in this study is accepted.

d) $\mathrm{H} 3 \mathrm{~d}$

The test results of the Vendor Quality indicator have a positive and significant effect on the Environment with a $\mathrm{P}$ value of $0.000 \leq 0.05$ and a T-Statistic value of $13.668>$ t-table 1.96 thus $\mathrm{H} 3 \mathrm{~d}$ in this study is accepted.

Based on the test results, it shows that the intention to adopt e-commerce by SMEs in Karawang Regency is proven not to be directly influenced by the technology aspect, but rather the organizational and environmental aspects.

\section{CONCLUSION}

Based on the results of the study, it shows that SMEs in Karawang Regency agree that aspects of technology, organization, and the environment support the adoption of e-commerce. Social commerce is most widely used by SMEs as a medium for increasing productivity. Based on the assumptions made by researchers, it is proven that the technological aspects do not have a significant effect on the intention to adopt e-commerce, while the organizational and environmental aspects have a significant effect on the intention to adopt e-commerce. All technology indicators, namely compatability, perceived usefulness, complexity, security concern and relative advantage, are proven to have a significant effect on technology in the intention to adopt e-commerce.

Organizational indicators, namely cost, organization readiness, organization culture, organization size and top management support, are proven to have a significant effect on organizations in their intention to adopt e-commerce. Meanwhile, environmental indicators, namely government support, competitive pressure, environmental uncertainty and vendor quality, have a significant effect on the environment in the intention to adopt e-commerce. In this study, the sample is limited to SMEs who are willing to fill out the questionnaire. During the data collection process, many SMEs were reluctant to fill out the questionnaire, so that only 301 respondents were obtained. Of course, these respondents do not represent all SMEs within the scope of Karawang Regency completely. For future researchers, they are able to develop this research by using other adoption models such as UTAUT, Diffusion Innovation, and others. In addition, the Karawang Cooperative and MSMEs Office as the agency that manages SMEs, in order to provide more education about ecommerce, because some respondents were reluctant to fill out questionnaires because they did not understand e-commerce.

\section{REFERENCES}

[1] depkop, "Perkembangan Data Usaha Mikro , Kecil , Menengah Dan Usaha Besar," 2018. 
[2] J. Jauhari, "UPAYA PENGEMBANGAN USAHA KECIL DAN MENENGAH (UKM) DENGAN MEMANFAATKAN E-COMMERCE."

[3] H. Magdalena, "Strategi Memanfaatkan E-Commerce Dalam Memasarkan Makanan Khas Bangka ( Studi Kasus: Aneka Citra Snack ) The Strategy of Exploiting ECommerce in The Marketing Of Bangka Peculiar Food ( Case Study: Aneka Citra Snack )," Cogito Smart, vol. 3, no. 2, pp. 286-298, 2017.

[4] M. M. Hakim and M. Nurkamid, "Model Adopsi Ukm Di Kudus Terhadap ECommerce," Simetris J. Tek. Mesin, Elektro dan Ilmu Komput., vol. 8, no. 1, pp. 339344, 2017, doi: 10.24176/simet.v8i1.974.

[5] F. Darnis, R. A. Azdy, ) Stmik, and P. J. B. Rahmat, "Pemanfaatan Media Informasi Website Promosi (e-Commerce) sebagai Upaya Peningkatan Pendapatan UMKM Desa Pedado," Sindimas, vol. 29, no. 1, pp. 275-278, 2019.

[6] M. Veranita, Y. Syahidin, and G. Gunardi, "Mengembangkan Ukm Melalui Pelatihan Internet Marketing Di Kecamatan Lengkong Kota Bandung," KUAT Keuang. Umum dan Akunt. Terap., vol. 1, no. 1, pp. 41-48, 2018, doi: 10.31092/kuat.v1i1.461.

[7] A. N. Rachman and Cecep Muhamad Sidik Ramdani, "IbM PELATIHAN PEMANFAATAN E-COMMERCE SEBAGAI MEDIA PEMASARAN GLOBAL UNTUK PENINGKATAN PENJUALAN PRODUK KELOM GEULIS (Studi Kasus: UKM kelom geulis Tamansari Tasikmalaya)," J. Siliwangi, vol. 2, no. 1, pp. 64-68, 2016.

[8] A. Wardhana, "Strategi Digital Marketing dan Implikasinya Pada Keunggulan Bersaing UMK di Indonesia," Semin. Nas. Keuang. dan Bisnis IV, no. April 2015, pp. 327-337, 2015.

[9] A. H. Purwantini and F. Anisa, "Analisis Pemanfaatan Social Commerce bagi UMKM: Anteseden dan Konsekuen,” Kompartemen J. IIm. Akunt., vol. 16, no. 1, pp. 47-63, 2018, doi: 10.30595/kompartemen.v16i1.2413.

[10] S. Mumtahana, Hani Atun, Nita and A. W. Tito, "khazanah informatika Pemanfaatan Web E-Commerce untuk Meningkatkan Strategi Pemasaran," Pemanfaat. Web ECommerce untuk Meningkat. Strateg. Pemasar., vol. 3, no. 1, pp. 6-15, 2017.

[11] Helmalia and Afrinawati, "Pengaruh E-Commerce Terhadap Peningkatan Pendapatan Usaha Mikro Kecil Dan Menengah Di Kota Padang," JEBI (Jurnal Ekon. dan Bisnis Islam)., vol. 3, no. 2, p. 237, 2018, doi: 10.15548/jebi.v3i2.182.

[12] G. D. Morris, S. McKay, and A. Oates, "Chapter 9 - E-commerce," Financ. Dir. Handb. (Fifth Ed., pp. 403-417, 2009, doi: 10.1016/B978-0-7506-8701-0.00009-6.

[13] C. Jaag and C. Bach, The Effect of Payment Reversibility on E-commerce and Postal Quality, no. 2010. Elsevier Inc., 2015.

[14] Merdeka.com, "B2B e-commerce makin cerah, UMKM jadi incaran," 2016. .

[15] Tempo.co, "87.574 UMKM di Karawang Terdaftar Menerima Bantuan Modal," 2020. .

[16] F. D. Davis, R. P. Bagozzi, and P. R. Warshaw, "User Acceptance of Computer Technology: A Comparison of Two Theoretical Models," Manage. Sci., vol. 35, no. 8, pp. 982-1003, 1989, doi: 10.1287/mnsc.35.8.982.

[17] F. D. Davis, "A technology acceptance model for empirically testing new end-user information systems: Theory and results," Management, vol. Ph.D., no. January 1985, p. 291, 1985, doi: oclc/56932490.

[18] I. Ajzen, “Ajzen.From Intentions to Actions-TPB.1985.pdf." 1985.

[19] I. Ajzen, "The Theory of Planned Behavior," pp. 179-203, 1991, doi: 10.1080/10410236.2018.1493416.

[20] V. Venkatesh, M. G. Morris, G. B. Davis, and F. D. Davis, "Human Acceptance of Information Technology," Int. Encycl. Ergon. Hum. Factors, Second Ed. - 3 Vol. Set, vol. 27, no. 3, pp. 425-478, 2003, doi: 10.1201/9780849375477.ch230.

[21] L. G. Tornatzky et al., "The Process of Technological Innovation: Reviewing the 
Literature," Natl. Sci. Found., no. May, pp. x, 264, 1983.

[22] Y. K. Dwivedi, M. R. Wade, and S. L. Schneberger, "Informations Systems Theory: Vol.2," Springer, vol. 28, p. 461, 2012, doi: 10.1007/978-1-4419-6108-2.

[23] T. Mahakittikun, S. Suntrayuth, and V. Bhatiasevi, "The impact of technologicalorganizational-environmental (TOE) factors on firm performance: merchant's perspective of mobile payment from Thailand's retail and service firms," J. Asia Bus. Stud., no. October, 2020, doi: 10.1108/JABS-01-2020-0012.

[24] S. S. Abed, "International Journal of Information Management Social commerce adoption using TOE framework: An empirical investigation of Saudi Arabian SMEs," Int. J. Inf. Manage., vol. 53, no. October 2019, p. 102118, 2020, doi: 10.1016/j.ijinfomgt.2020.102118.

[25] A. Gui, Y. Fernando, M. S. Shaharudin, M. Mokhtar, I. G. M. Karmawan, and Suryanto, "Cloud computing adoption using toe framework for Indonesia's micro small medium enterprises," Int. J. Informatics Vis., vol. 4, no. 4, pp. 237-242, 2020, doi: 10.30630/joiv.4.4.458.

[26] A. Kumar and B. Krishnamoorthy, "Business Analytics Adoption in Firms: A Qualitative Study Elaborating TOE Framework in India," Int. J. Glob. Bus. Compet., vol. 15, no. 2, pp. 80-93, 2020, doi: 10.1007/s42943-020-00013-5.

[27] S. Kosasi, "Analisis Kritis Adopsi E-Commerce Untuk Pasar Ekonomi KreatifMelalui Kerangka Teknologi-Organisasi-Lingkungan,” vol. 8, no. 9, pp. 13-24, 2017.

[28] R. Sandu and E. Gide, "Technological, Organisational and Environmental (TOE) Factors that Influence the Adoption of Cloud Based Service SMEs in India," IEEE Int. Conf. Cloud Comput. CLOUD, vol. 2018-July, pp. 866-870, 2018, doi: 10.1109/CLOUD.2018.00123.

[29] M. I. Effendi, D. Sugandini, and Y. Istanto, "Social Media Adoption in SMEs Impacted by COVID-19: The TOE Model*," J. Asian Financ. Econ. Bus., vol. 7, no. 11, pp. 915-925, 2020, doi: 10.13106/jafeb.2020.vol7.no11.915.

[30] M. Paredes and Á. Rocha, Information technology and systems, vol. 2018, no. E17. Springer International Publishing, 2019.

[31] A.-M. Stjepić, M. Pejić Bach, and V. Bosilj Vukšić, "Exploring Risks in the Adoption of Business Intelligence in SMEs Using the TOE Framework," J. Risk Financ. Manag., vol. 14, no. 2, p. 58, 2021, doi: 10.3390/jrfm14020058.

[32] H. N. Rawash, "E-commerce Adopting TOE Model by SMEs in Jordan E-commerce Adopting TOE Model by SMEs in Jordan," Multicult. Educ., vol. 7, no. 3, pp. 118-122, 2021, doi: 10.5281 /zenodo.4598098.

[33] M. Skafi, M. M. Yunis, and A. Zekri, "Factors influencing SMEs' adoption of cloud computing services in Lebanon: An empirical analysis using TOE and contextual theory," IEEE Access, vol. 8, pp. 79169-79181, 2020, doi: 10.1109/ACCESS.2020.2987331.

[34] A. Pateli, N. Mylonas, and A. Spyrou, "Organizational adoption of social media in the hospitality industry: An integrated approach based on DIT and TOE frameworks," Sustain., vol. 12, no. 17, 2020, doi: 10.3390/su12177132.

[35] C. E. Ocloo, H. Xuhua, S. Akaba, J. Shi, and D. K. Worwui-Brown, "The Determinant Factors of Business to Business (B2B) E-Commerce Adoption in Small- and MediumSized Manufacturing Enterprises," J. Glob. Inf. Technol. Manag., vol. 23, no. 3, pp. 126, 2020, doi: 10.1080/1097198X.2020.1792229.

[36] C. Sayginer and T. Ercan, "Understanding determinants of cloud computing adoption using an integrated diffusion of innovation (Doi)-technological, organizational and environmental (TOE) model," Humanit. Soc. Sci. Rev., vol. 8, no. 1, pp. 91-102, 2020, doi: $10.18510 /$ hssr.2020.8115. 
[37] J. C. F. Li, "Roles of individual perception in technology adoption at organization level: Behavioral model versus toe framework," J. Syst. Manag. Sci., vol. 10, no. 3, pp. 97118, 2020, doi: 10.33168/JSMS.2020.0308.

[38] H. Ehrari, F. Ulrich, and H. B. Andersen, "Concerns and trade-offs in information technology acceptance: the balance between the requirement for privacy and the desire for safety," Commun. Assoc. Inf. Syst., vol. 47, pp. 227-247, 2020, doi: 10.17705/1CAIS.04716. 